\title{
Public Participation For Local Based Tourism Development In Kampoeng Dolanan Jamus Kauman Tourism Village
}

\author{
Rina Susanti ${ }^{1}$, Sasiana Gilar Apriantika ${ }^{2}$, V.Indah Sri Pinasti ${ }^{3}$ \\ Universitas Negeri Yogyakarta \\ rinas7797@gmail.com
}

\begin{abstract}
The background of this research is public eagerness to preserve the local culture and to increase public's prosperity in Kampoeng Dolanan Jamus Kauman Tourism Village. This research aims to identify the form of public participation, applied strategy, and the impacts of tourism village development efforts. Qualitative descriptive method was used with 10 chosen informants as the sample since purposive sampling technique used in this research.. The data collection techniques which were used are interviews, observations, and literature studies. Data validity was done by source triangulation, then analyzed using interactive technique by Miles and Huberman. The result of the study showed that the public had participated directly and indirectly by giving their thought, efforts, and skill. The society analyzed the potentials and establishing cooperation with other party as the development strategy, affecting both positively and negatively for Kampoeng Dolanan Jamus Kauman Tourism Village society.
\end{abstract}

Keywords. Participation, Development Strategy, The Impact of Tourism Village

\section{Introduction}

Indonesia is a rich country with natural resources and human resources. But until now not all natural resources and human resources are utilized completely for the prosperity of the society. The high number of people who are still living under the poverty line is a sign that the society has not fully utilized the natural richness of Indonesia. The Central Statistic Agency (BPS) research stated that in September 2017, the number of poor people (the population with per capita spending per month under the poverty line) in Indonesia reached 26.58 million people or $10.12 \%$ of the total population in Indonesia. Based on the problems, the development of both natural resources and human resources are needed to overcome the problem of poverty in Indonesia.

Tourism is one of the development sectors that are currently being coordinated by the government. Developments in the field of tourism have a very important role in the development in Indonesia, especially in foreign exchange producers. Tourism in Indonesia is one of the important economic sectors, because tourism is an interesting attraction to reduce unemployment. Law Number 10 year 2009 about tourism, stated that the development of tourism is necessary to promote the equality of the opportunity to strive and benefit and to face the challenges of changing local life, national, and Global. Tourism is currently one aspect that cannot be ruled out, but rather a tourism is one of the very important needs.

According to Maslow in Ujam Jaenudin (2015:143) He proposed a five-storey hierarchy consisting of physiological needs, security, love, appreciation and self-actualization. Later on, he added two more needs, namely the need to know and understand, and aesthetic needs. He also said that one does not need to satisfy the needs of one level entirely before moving the 
following levels, and therefore it can happen that the person is partially satisfied and not satisfied partly for all levels in the Hierarkhi at the same time. Then it can be said that the need for tourism becomes important in the work activity that is time-consuming and so tourism becomes a thing of refreshing means of routine. Successful tourism development is a tourism development conducted jointly so that the development of tourism can provide economic, social and cultural benefits to local people. The purpose of tourism involving the community is that it is an effort to empower people through tourism development, improving the role and participation of the community in order to gain economic, social, and cultural benefits from tourism development, providing a balanced opportunity to all members of the community both male and female. One of the interesting tourism manifestations offered is the tourism village Kampoeng Dolanan with the form of tourism that relies on local wisdom of society.

Kampoeng Dolanan Jamus Kauman tourism village is one of tourism that aims to introduce local culture to the society. Kampoeng Dolanan Tourism Village involves local society in the process of development as well as developments. The Kampoeng Dolanan Tourism Village is one of the efforts to improve the welfare of the community as well as a cultural conservation effort. The tourism village of Kampoeng Dolanan Jamus Kauman describes the real life of the village along with the customs or traditions owned by the community. The potential of local wisdom of rural communities is one of the charms that can be developed for tourism activities. The characteristic of the village will also add value or attraction for visitors who come.In this research to discuss in depth the results of data found then researchers use the theory of the results of the development of the great theory of functional Strruktural, with the study of the Library, among others: tourism Village, rural tourism rural, local wisdom and community participation in developing the Tourism object Kampoeng Dolanan with the approach of Community Based Tourism (CBT). The theory of Structural Functionalism explains and understands the process of building social reality in society by looking at the unit of focus in this theory, namely society as a system by carrying out their respective functions that are interrelated so as to create integration in society. Integration facilitates the construction process

\section{Method}

According to Sugiyono, a naturalistic qualitative design studies the occurrence of activities and processes naturally, where this method is planned or manipulated. Qualitative method are generally focused on exploration, disclosure, and inductive logic. The inductive design begin with observation the situation in the Kampoeng Dolanan Jamus Kauman Tourism Village. Analyrical dimension arise from open -ended observation. The data used in this research involved primary data, where data was directly obtained in data collection from a key informant and supplementary informants. The interview involved the representative society in the Kampoeng Dolanan Jamus Kauman Tourism Village. The secondary data was obtained from analytical observation of literature studies

\section{Results and Discussion}

The village of tour Kampung Dolanan Jamus Kauman began to open in 2014 by citizens as its founder. The existence of the Kampoeng Dolanan Jamus Kauman is very welcomed and 
supported by the government of Jamus Kauman village. The government of Jamus Kauman Village finally inaugurated and appointed Karanggeneng Hamlet as a tourism village Kampoeng Dolanan Jamus Kauman. This Kampoeng Dolanan carries the theme of local wisdom of the village community to be an attraction to this attraction. This Kampoeng Dolanan teaches visitors to learn about the real-life of the village with a variety of activities in the form of traditional games developed in the village tourism Kampoeng Dolanan Jamus Kauman. Rural People's life presents customary or habitual practice and becomes a hallmark of the region. The effort to preserve the customs is packaged into a tour package. Aspects of tourism developed by the community include: traditional games, arts, traditions, typical food and crafts, natural beauty, and real life of the countryside.

Local wisdom-based tourist villages refer to the physical and non-physical potential developed to attract tourists. Physical potential developed in the village tourism Kampoeng Dolanan Jamuskauman is like natural atmosphere that is still naturally with a variety of beautiful plants, a wide river with a heavy river flow, vast expanses of paddy fields, and the presence of various types of vegetable plants that can be utilized to support the development of tourism villages (cassava plants, Salak, Melinji and banana trees). In addition, non-physical potential is owned namely a harmonious and compact community condition. In addition, visitors can also directly engage with various activities of the population such as traditional game play (Egrang, Gangness, Bas-Basan, Macanan, etc.), traditionally farming, cooking taradisional food, witnessing the traditions of society (Bancakan, a handful), the regional arts (the dance Kubro Siswo and Karawitan), and stay a few days in the House of citizens to deepen the country life.

The tourism village of Kampoeng Dolanan Jamus Kauman involves the participation of village devices, the peasant Women's Group (KWT) and the general public. The people involved are the head of village, chairman of RT, Karang Taruna and the general public of Sub Village Karanggeneng. Public participation in the process of development of Kampoeng Tourism village Dolanan Jamus Kauman. Classified into 2 based on its form include direct participation and indirect participation. While community involvement is divided into three kinds, among others, in the form of thought, efforts and skill

a. Direct participation

Direct community involvement in the Kampoeng Dolanan Jamus Kauman tourism village is a manager and merchant in the tourist activities area. In addition, people from young to old are actively involved in welcome activities until the dissolution.

b. Indirect participation

The involvement of Community Kampoeng Dolanan Jamus Kauman tourism village indirectly is to contribute to the contribution of ideas or thoughts. Such ideas or thoughts are poured through formal and non-formal meetings or gatherings. In addition, there is a routine meeting every 3 months in the village hall to report activities in each Hamlet. While community involvement is divided into three kinds :

1. Participation in the form of thought

Active communities in regular meeting activities to discuss the progress of the village. The Agenda of the meeting is conducting an evaluation in each tourism activity for joint repairs and comfort

2. Participation in the form of effort

Participation in the form of energy is seen in the process of development of the Kampoeng Dolanan Jamus Kauman tourism village, which participates in each village activity. The real form is involved in the activities of the work, the night Ronda, etc. In addition, people are also involved as guides, merchants, and managers of tourist villages. 


\section{Participation in the form of skill}

The Community of Kampoeng Dolanan Jamus Kauman tourism village not particularly demonstrated its participation in the form of expertise, only a small part of the village community that gives the expertise it has. Community-owned expertise in tourism

The development of tourism village is not detached from the business that is done by the local community itself. Tourism must also appreciate the customs, preserve the environment and give a real positive impact and can be enjoyed by the community surrounding the tourist attractions. Each village has certain advantages that are uniqueness of life pattern with handicraft products, art typical area or village. Thus with the condition of rural tourism that causes the needs of the active participation of the community as the development of local wisdom-based tourism village. Local wisdom-based tourism Village development strategies need to pay attention to the following things:

Table 1. Table of applied strategi development in Kampoeng Dolanan Jamus Kauman Tourism Village Strategy development Description

\begin{tabular}{|c|c|}
\hline Strategy development & Description \\
\hline Analyze potential of tourism village & $\begin{array}{l}\text { Tourism today does need to boast of the potential of } \\
\text { each region as a characteristic. This characteristic is } \\
\text { very important because it can be a differentiator } \\
\text { between one tourist and another. Kampoeng Dolanan } \\
\text { Jamus Kauman tourism village is a local wisdom- } \\
\text { based tour. Kampoeng Dolanan Jamus Kauman } \\
\text { tourism village has a tourism concept that uses } \\
\text { natural resources and local human resources. } \\
\text { Kampoeng Dolanan Jamus Kauman tourism village } \\
\text { offers tourism by relying on traditional games, local } \\
\text { art, typical food, and the life of rural people. }\end{array}$ \\
\hline Analyze problem of tourism villlage & $\begin{array}{l}\text { The opening of the Kampoeng Dolanan Jamus } \\
\text { Kauman tourism village is not without reason. } \\
\text { Departing from local community issues that are the } \\
\text { majority of people who have widows status. This } \\
\text { Status is one of the considerations of people to } \\
\text { develop economic income to meet the growing needs } \\
\text { of life. Community shoulder shoulder to trigger an } \\
\text { idea to create a tourism village which is then } \\
\text { supported also by the government of Jamus Kauman } \\
\text { village. }\end{array}$ \\
\hline People's desire to develop & $\begin{array}{l}\text { Community Village Tourism Kampoeng Dolanan } \\
\text { Jamus Kauman very pleased with the opening of this } \\
\text { attraction. Many people feel positive benefits. The } \\
\text { most noticeable and perceived thing is the } \\
\text { increasingly compact and harmonious community. } \\
\text { With the participation and activities deliberations } \\
\text { can add a sense of unity among citizens. In addition, } \\
\text { the solidarity that is seen in the Ronda activities that } \\
\text { the residents do every night interchangeably. The } \\
\text { activities of Gotong-Royong are also held regularly } \\
\text { and attended by all citizens. Environmental } \\
\text { conditions are very organized, clean and tidy. }\end{array}$ \\
\hline Conduct training in tourism village & $\begin{array}{l}\text { The opening of the tourism village Kampoeng } \\
\text { Dolanan Jamus Kauman also received excellent } \\
\text { support from the government of Jamus Kauman } \\
\text { village. The form of support provided is by }\end{array}$ \\
\hline
\end{tabular}


establishing cooperation with other party providing directives regarding the arrangement of the environment. It aims to create tourism with adequate facilities and organised environmental conditions. It also held skills training to the community, such as: garbage recycling training, handicraft training, soft skills training, etc.

Currently, the village of Kampoeng Dolanan tourism is already into the enchantment of Indonesia which means it has become a recommendation of tourist destinations worthy of tourists. The development of the tourism village Kampoeng Dolanan Jamus Kauman has a tour and travel to bring guests from various regions. In addition, Kampoeng Dolanan Jamus Kauman Tourism Village also belongs to the network of Tourism villages (Jadesta). This tourism Village network is a program created by the Ministry of Tourism and the creative Economy (KEMENPAREKRAF)

Karanggeneng Sub Village is a society that has strong social integration among its citizens. This is evidenced by the exposure of all interviewings as well as the results of the researchers ' observation tht the community is very harmonious among one another. The development of Kampoeng Dolanan Tourism Village is formed on the initiative of local people. Surely in every development both physical and non physical will pose an impact that will be perceived by the community. Along with this Kampoeng Dolanan Jamuskauman people feel a lot of changes that occur from before. The changes appear to be no other because guests or tourists visit so that there are various livelihoods or economic activities of the Community i.e. merchants and tourist Pegelola. As for any development or tourism development will be felt impact for the community. The findings concluded that many positive impacts were felt from the negative impacts. One informant says that many of the positive impacts of negative impacts

Table 2. Table the impact of Kampoeng Dolanan Jamus Kauman Tourism Village development

\begin{tabular}{cll}
\hline Aspect & \multicolumn{1}{c}{ Positive impact } & \multicolumn{1}{c}{ Negative impact } \\
\hline Social & $\begin{array}{l}\text { Increasing social interaction } \\
\text { Open insight and knowledge } \\
\text { Improved facilities and infrastructure }\end{array}$ & $\begin{array}{l}\text { The emergence of community discomfort } \\
\text { Prejudice appears so that social control } \\
\text { does not work }\end{array}$ \\
Economic & $\begin{array}{l}\text { Improved environmental cleanliness } \\
\text { Increasing public income } \\
\text { preserve public eagerness } \\
\text { Maintenance of traditional art and } \\
\text { culture }\end{array}$ & $\begin{array}{l}\text { Seasonal merchant competition } \\
\text { The entry of foreign cultures that affect } \\
\text { young people }\end{array}$ \\
\hline
\end{tabular}

\section{Conclusions}

From this research it can be concluded that public participation given by the Kampoeng Dolanan jamus Kauman Tourism Village Kauman is divided into several types and forms. Based on its involvement, there are two kinds of participation given by direct participation and 
indirect participation. Participation is also divided into several forms in the thought, efforts, and skill.

Applied strategy development in Kampoeng Dolanan Jamus Kauman Tourism Village based local culture. The society analyzed the potential and the problem that can be used an attraction is the characteristic of Kampoeng Dolanan Jamus Kauman Tourism Village. The efforts are carried out by Jamus Kauman Village government, namely by providing environmental management guidance, waste recycling training, craft training, soft skills training, etc. In addition, it also establishing cooperation with other party, such as tours and travel and other attractions.

After the emergence of Kampoeng Dolanan Jamus Kauman Tourism Village had positive and negative impacts. The impact caused involves social, economic and cultural aspects. The positive social impacts include increasing community social interactions, opening community insights and knowledge, improving facilities and infrastructure and increasing environmental hygiene. Negative social impact is the emergence of public discomfort and the emergence of social prejudice. While the positive economic impacts include increasing community income and improving people's prosperity. Negative economic impacts of competition between traders. The impact of positive culture is the preservation of traditional arts and culture of society. Negative cultural impacts include foreign influences to young people.

\section{References}

[1] Agus Wibowo dan Gunawan. 2015. Pendidikan Karakter Berbasis Kearifan Lokal di Sekolah. Yogyakarta : Pustaka Pelajar.

[2] Damanik, J. (2013). Pariwisata Indonesia antara Peluang dan Tantangan. Yogyakarta: Pustaka Pelajar.

[3] Hastuti \& Respati SS, Dyah. (2009). Model Pemberdayaan Perempuan Miskin Berbasis Pemanfaatan Sumberdaya Perdesaan Upaya Pengentasan Kemiskinan di Perdesaan Lereng Merapi Selatan. Jurnal Humaniora, Vol 14, No 1 : 5-6.

[4] Ibrahim, J.T. (2003). Sosiologi Pedesaan. Malang: Universitas Muhammadiyah Malang.

[5] Jaenudin, Ujam. (2015). Teori-teori Kepribadian. Bandung : CV Pustaka Setia.

[6] Komariah, Neneng. (2018). Pengembangan Desa Wisata Berbasis Kearifan Lokal. Jurnal Pariwisata Pesona, Vol 3, No 2:165-167.

[7] Kriska, Mesalia. (2019). Partisipasi Masyarakat dalam Community Based Tourism di Desa Wisata Puton Watu Ngelak Kabupaten Bantul.JSEP, Vol 12, No 1:16-20.

[8] Kristiana,Yustisia. (2019). Buku Ajar Studi Eko Wisata. Yogyakarta: CV Budi Utama

[9] Nurhayati, S. E. (2012). Penerapan Prinsip Comunity Based Tourism (CBT) Dalam Pengembangan Agrowisata Di Kota Batu, Jawa Timur. Jejaring Administrasi Publik, 37-38.

[10] Pemerintah Jamus Kauman. (2016). http://desajamuskauman.magelangkab.go.id (Diakses pada tanggal 6 Maret 2020 pukul 12.40 WIB).

[11] Prayit.(2015).http://kampoengdolananjamuskauman.blogspot.com/p/contact-us.html. (Diakses pada 22 November 2019 pukul 09.30 WIB).

[12] Purwanggono, D. (2009). Konsep Desa Wisata. Jurnal Pariwisata, 4(2), 2. Diakses pada jurnal.stpss.ac.id/index.php/JPI/article/view/13.

[13] Reportase.https://20.detik.com/spot-wisata/20190429-190429073/desa-wisata-kampung-dolananmagelang. (Diakses pada 22 November 2019 pada pukul $12.10 \mathrm{WIB}$ ).

[14] Ross, Glenn F. (1998). Psikologi Pariwisata. Jakarta: Hospitality Press.

[15] Soekanto, Soerjono. (2014). Sosiologi Suatu Pengantar. Jakarta : Rajawali Pers.

[16] Sugiyono. (2011). Metode Penelitian Kuantitatif Kualitatif dan R\&D. Bandung: Alfabeta. 
[17] Takariadinda, E. 2016. Pengembangan Pariwista Berbasis Budaya Berdasarkan Undang-undang Nomor 10 Tahun 2009 di Kabupaten Sleman. Jurnal Kajian Hukum. 1(2).

[18] Taneko, S.B. 1984. Struktur dan Proses Sosial, Suatu Pengantar Sosiologi Pembangunan. Jakarta: CV. Rajawali.

[19] Widyastuti, N. A. (2017). Partisipasi Masyarakat Dalam Pengembangan Desa Wisata Kebon Agung di Imogiri Bantul Yogyakarta. Journal StudentVol 6:11-12.

[20] Zahrulianingdya, Atiek. (2018). Kuliner Sebagai Pendukung Industri Pariwisata Berbasis Kearifan Lokal. Jurnal TEKNOBUGA, Vol 6, No 1:1-7. 